\title{
An Approach to Digital Game-based Learning: Video-games Principles and Applications in Foreign Language Learning
}

\author{
Ricardo Casañ Pitarch \\ Univeresitat Politècnica de València, Spain
}

\begin{abstract}
During the present decade, researchers and educators of different fields have increased their attention towards digital game-based learning. The rise of interest towards this approach is partially connected to some important technological advances during the same period of time, such as the Smartphone, enhanced Internet connection from mobile devices, diversity and spread of free and low-cost video-games and educational applications in e-stores, development of speech recognition systems and artificial intelligence, among others. More concretely, this research focuses on the area of foreign language learning, an educational field which requires that students gain not only a solid theoretical knowledge on grammar and vocabulary, but they also need to develop different communicative competences; and this implies rehearsing and experiencing the use of the target language. The purpose of this paper is to define some basic concepts related to digital game-based learning, such as gamification and serious games, and to introduce some theoretical principles on foreign language learning and acquisition through the use of video-games based on literature review. Finally, a connection among these elements will be discussed.
\end{abstract}

Index Terms - serious video-games, gamification, digital game-based learning, language learning

\section{INTRODUCTION}

People and society are continuously changing together. The development of new ideas and inventions has led to build new perspectives and visions towards the world. In this sense, what it had been once considered revolutionary and original finally became obsolete. This process of changing from innovative to obsolete is a matter of evolution, a universal truth that has been constant throughout history beyond mankind. No one can question that evolution is present in any single aspect of life, and this involves education matters as well. In this case, education has always evolved towards the needs of society in any particular period of time or place; however, the speed of this evolution has been different along history. In the decades from the 1960s to the 1980s, changes in education became more significant after the earliest cognitivist studies (see Ausubel, 1968; Bruner, 1966, Chomsky, Lakoff or Piaget, 1952, among others); whereas more recently, some relevant inventions and advances in technology such as the computer, the internet or the smartphone among many others have made the evolution process more evident in the eye of science (Harris, 2012; Pechenkina, Laurence, Oates, Eldridge, \& Hunter, 2017). As result, technology and education have especially gone hand-in-hand in contemporary times, and this fact has given rise to new perspectives in life (Loveless, \& Williamson, 2013; Selwyn, \& Bulfin, 2016).

Researchers from different educational fields are constantly questioning the educational models from the last century that still remain in the present educational centers (Wilson, 2014). Some of these discussions revolve around the fact that the way current students find motivation differs vastly from those in the past (Buchanan \& Elzen, 2012; Prensky, 2001; Qian, \& Clark, 2016). In this line, even though the use of games as a pedagogical resource is not new in learning centers around the world, game-based approaches are gaining ground to other more theoretical teaching methods thanks to the introduction of technological resources that are attractive to students and have introduced new applications and possibilities (Eseryel, Law, Ifenthaler, Ge, \& Miller, 2014). Thus, this paper focuses on reviewing the connection between digital game-based learning and the process of foreign language learning through video-games, both conventional and serious ones. To this purpose, this paper defines the concepts of serious video-games, gamification and digital game-based learning and then it focuses on explaining how learning languages is processed from the initial stage (input) to the production one (output) in the digital game-based approach.

\section{Definition of Three Basic Concepts: Serious Games, GAMificAtion AND DigitAl GAME-BASED LEARNING}

\section{A. Serious vs Conventional Video-games}

Contrary to the primary purpose of conventional games, serious games aim at teaching specific content rather than being pure entertainment for the player (Calvo-Ferrer, 2018). However, this does not imply that serious games should not remain loyal to the main principle of conventional games: to provide entertaining (Oliveira, Correia, Merrelho, Marques, Pereira, \& Cardoso, 2009; González-González, \& Blanco-Izquierdo, 2012). Thus, serious games seems to be 
characterized for combining and integrating both teaching and entertainment in simulations, and consequently they could not be understood as such if any of these two features are omitted.

In order to make this definition clearer, serious games should be distinguished from conventional ones. In this sense, it shall be acknowledged that all video-games are educational and the difference between one and the other lies in the fact that serious games are designed on purpose for teaching aims (Bellotti, Kapralos, Lee, Moreno-Ger \& Berta, 2013; Escribano, 2012). Thus, any game involve educational factors even if they have exclusively been designed for playing aims (Reinders, 2012). Some examples of games used for pedagogical aims are Who is Who and Domino, whereas some examples of video-games are World of Warcraft and The Sims. On the hand, serious games are designed to teach specific content and the play aspect remains secondary. However, in line with this statement, the play aspect is the primary basis of any conventional video-game; and thus, serious video-games should not be understood as such without it. As result, the play aspect seems to be one of the main sources to motivate students; in this sense, if students effort through playing, it is more likely that they will learn (Dondlinger, 2007). The reasoning for this assertion is that fostering motivation among students shall increase their efforts to complete the task and promote their enjoyment during the gaming time (Gros, 2009). Some examples of serious video-games are Combat Medic and Hilton Ultimate Team Play (designed by Virtual Heroes), Hazmat: Hotzone (designed by Carnegie Mellon University), and Anti Money Laundering (designed by Playgen), among many others. For the aim of this research, this paper will only focus on video-games from now on.

In addition to this introduction to serious video-games, it shall be acknowledged that the use of serious video-games in the classroom is not new (see Gagnon, 1985; Malone, 1981; Silvern, 1986); yet, technological barriers have made that their application was not accessible for most educational centers and students until approximately the decade of the 2010, coinciding with the launch of portable devices such as the Smartphone or the Tablet. Since the origin of their application in the classroom, numerous researchers and teaching professionals have described their experiences with serious video-games and enumerated the main characteristic and benefits that they have identified. One of the first researchers who described the characteristics of serious video-games was Malone (1981). In this sense, this author suggested that serious video-games need to establish clear meaningful learning and playing goals for the students, and providing continuous feedback on their progress. As its video-game nature, the difficulty must be adapted to the learners' skills and rise progressively according to the learning aims. Besides, it should also provide elements of surprise to break monotony. Similarly, Susi, Johannesson and Backlund (2007) provided a description of the main characteristics of this type of video-games which highlighted the importance of task-solving in a scenario where communication should be natural. In this line, Sampson and Karagiannidis (2002) also appointed task-solving as one of the most relevant principles in electronic education. This suitability to introduce tasks in serious games could be justified with the fact that the best learning comes from experience (Cohen, 2007; Jarvis, 2009) and video-games allow that players solve tasks while playing (Ziegler, 2016). As result, this fact makes that the learning process becomes engaging and motivating.

At last, it also needs to be acknowledged that serious video-games are a subtribe among video-games. Therefore, they share some characteristics with conventional video-games that must be considered. To this purpose, Calvo-Ferrer (2018) clearly explains, in words of Gee (2005), the features that are shared between both conventional and serious video-games. In this sense, good video-games should have an attractive design, customized difficulty levels, power of manipulation, characters with identity and well-ordered problems. Besides, feedback must be continuous (as previously stated by Malone [1981]), but this should also be challenging, provided on demand and in the necessary time; and in addition, it should respect the circle of expertise before moving to the next stage: tutorial, practice and testing. Finally, regarding how video-games transfer knowledge to their players, Gee (2005) identifies two principles: system thinking and meaning as action image. The first one implies that the game should help players see and understand how the different elements fit into the game. The second one, meaning as action image, aims at teaching through actions and experiences rather than on lectures.

\section{B. Gamification}

Gamification is the process from which games can be adapted to particular teaching purposes in the classroom (Werbach, 2014). Having defined serious games and introduced its characteristics and benefits, gamification could be understood as the mechanism used to integrate different games in a lesson or the curriculum (Molin, 2017). Thus, gamification implies that teachers and lecturers can design lessons or subjects introducing a wide range of games with a particular linearity along them.

From a broad perspective, one of the most frequently used definitions among researchers for gamification is the one provided by Deterding, Dixon, Khaled and Nacke (2011), who explained that this process concerns "the use of game design elements in non-gaming contexts" (p. 12). Other authors have also provided their own definitions; in the case of Hamari, Koivisto and Sarsa (2014), they make special emphasis to the importance of emotions, as it has also been appointed in the description of serious games: "[gamification is] a process of enhancing services with motivational affordances in order to invoke gameful experiences and further behavioral outcomes" (p. 3025). In the practice, some researchers such as Werbach and Hunter (2012) or Robson, Plangger, Kietzmann, McCarthy and Pitt (2015) have previously suggested their own model of gamification, as it can be observed in figure 1. 


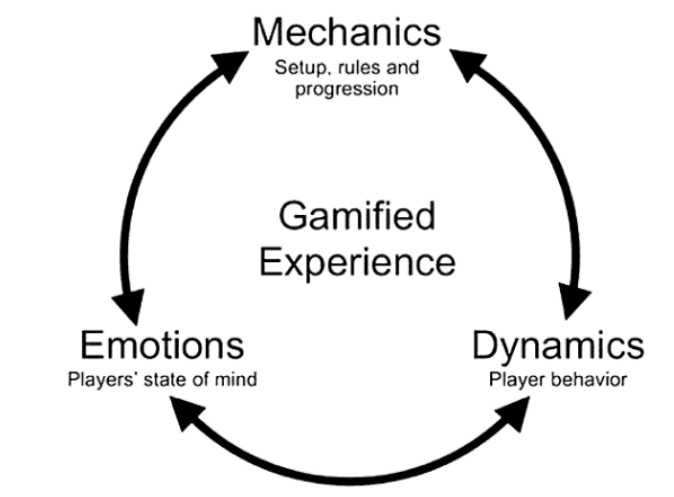

Figure 1. Processing Gamification (Robson et al., 2015, p. 416)

This model contains three elements that are defined in these lines. The first element is mechanics and it represents the objectives, rules, setting, context, interactions and boundaries within the game; its purpose is to promote action in the video-game and create engagement among players. The second one concerns dynamics; its aims at describing the functioning of the rules in the practice and at configuring the behavior of the players that participate in the experience. The last element in this model is emotions, which focuses on the players' affective states and reactions caused by the game. These feelings and emotions are what contribute to emotionally engage the player to play and consequently to learn.

The importance of emotions along both the gaming time as well as the learning process is fundamental to understand the benefits of learning through gamified resources. In this sense, Malone and Lepper (1987) identified two types of motivation to attract learners' attention: individual and interpersonal. On the one hand, the individual motivation concerns student's emotions towards challenge, control, curiosity and fantasy. On the other hand, there are three elements that influence on the learners' interpersonal motivation: cooperation, competence and recognition. As it can be observed in table 1, there are different elements that promote the players' individual and interpersonal motivation within each category.

TABLE 1.

TYPES OF MOTIVATION (MALONE AND LEPPER, 1987).

\begin{tabular}{|c|c|c|}
\hline \multirow{4}{*}{ Individual motivation } & 1. Challenge & $\begin{array}{l}\text { a. Goals } \\
\text { b. Uncertain Outcomes } \\
\text { c. Performance Feedback } \\
\text { d. Self-Esteem }\end{array}$ \\
\hline & 2. Curiosity & $\begin{array}{l}\text { a. Sensory Curiosity } \\
b . \text { Cognitive Curiosity }\end{array}$ \\
\hline & 3. Control & $\begin{array}{l}\text { a. Contingency } \\
\text { b. Choice } \\
\text { c. Power }\end{array}$ \\
\hline & 4. Fantasy & $\begin{array}{l}\text { a. Emotions } \\
\text { b. Cognition } \\
\text { c. Endogeneity }\end{array}$ \\
\hline Interpersonal motivation & \multicolumn{2}{|l|}{$\begin{array}{l}\text { 1. Cooperation } \\
\text { 2. Competence } \\
\text { 3. Recognition }\end{array}$} \\
\hline
\end{tabular}

As result of rising learners' motivation, it seems that emotions play a fundamental role in determining the success of the learning process. In addition, to the types of motivations introduced by Malone and Lepper (1987), Butler (2016) suggested that working on emotions in the gamification process is determined by four elements: engagement, autonomy, mastery and progression. The first element aims at connecting the player/learner with the content; providing storytelling, narrative and challenge help involve the players with the game. The second item in the list concerns autonomy. Videogames are characterized by allowing players control avatars, take their own decisions, explore the virtual world at their own pace and be the protagonists. As result, they get immersed in the learning process more easily and also engage them with intrigue and suspense. Next, mastery refers to the opportunity offered to students to exercise and repeat tasks until they are completely controlled. At last, progression is the main reward to students for their efforts. As far as they advance in the video-game, they feel motivated to continue playing until they fulfill the goal of the game while learning. As it can be observed, there is a clear connection between Butler (2016) and Malone and Lepper (1987) since they both focus on motivating students through the use of video-games. The difference lies in the fact that the first focus on elements that are necessary to motivate players through a gamified lesson, whereas the second aims at making a game engaging.

The combination of these prior pieces of research was previously used in our own research (Casañ-Pitarch, 2017a) with the aim of explaining the gamification process as well. In this case, our model of gamification was introduced following mainly Robson et al. (2015) and Butler (2016), as it is shown in figure 2. This model is divided into four rings 
and it needs to be interpreted from the inner circle to the outer layers. The inner circle has been slightly adapted to our interests in this research and it focuses on the teaching and learning purposes (what to teach). The second ring focuses on choosing the playing purpose (how to teach). In this sense, it is different teaching languages, music, algebra or science, among many others. Thus the educator needs to consider the pros and cons among the different games and methods, and then they can choose the most suitable according to their own criteria. Once the content and the gaming method have been chosen, the educator should manage to select a suitable video-game genre (i.e.: graphic adventures, puzzles) as the scenario for the teaching and method. The last step within the circles is the development of the videogame mechanics, dynamics and emotions in, as explained by Robson et al. (2015). This stage concerns the development of the video-game with its characters, story, context or awards, among many others. Finally, this process needs to be accompanied with the four elements introduced by Butler (2016) to incorporate feelings and emotions in the game and rise learners' motivation and engagement to play and consequently to learn.

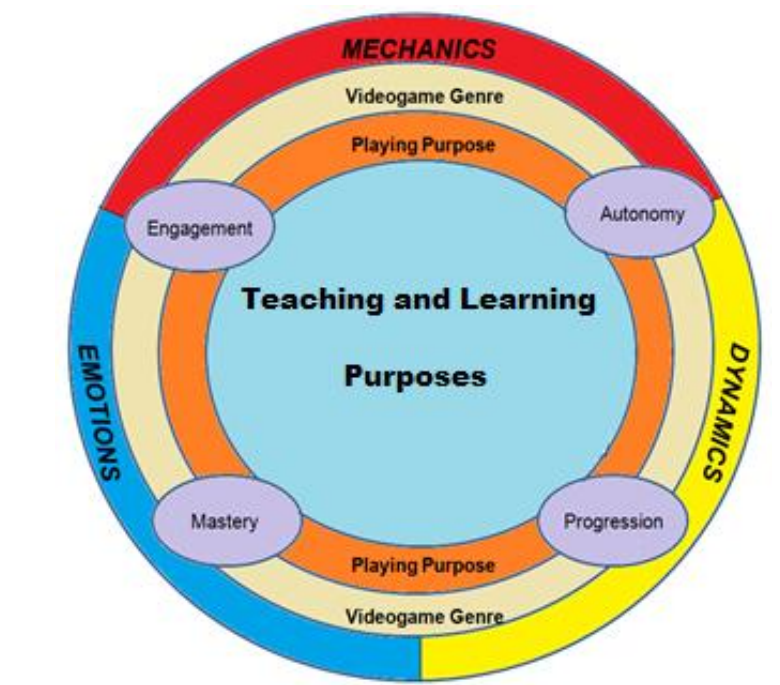

Figure 2. Gamification Process (Adapted from Casañ-Pitarch, 2017a, p.111).

\section{Digital Game-based Language Learning as an Approach}

As previously explained, gamification should be considered a mechanism from which any approach can be benefited from the application of games in the classroom (Kaur \& Geetha, 2015). The digital game-based learning is a pedagogical practice that has more recently derived from a broader term that involves the indistinctive use of both digital and non-digital resources (Deterding, Khaled, Nacke, \& Dixon, 2011). Consequently, introducing a well-defined distinction has been necessary in order to specify when technological resources are used in exclusive. In this sense, game-based learning could be considered the hypernym of digital game-based learning. In both cases, these approaches imply that the use of games can be implemented in non-playful environments (Aguiar-Castillo, Rufo-Torres, De SaaPérez, \& Pérez-Jimenez, 2018). Kirriemuir, \& McFarlane (2004) defined game-based learning as those "activities that have a game at their core, either as the main activity or as a stimulus for other related activities, and have learning as a desired or incidental outcome" (p. 7). The broadest difference between one and another is the fact that digital gamebased learning only concerns the use of electronic games for learning objectives. De Freitas (2006) explained that this digital educational approach focuses on the usage of electronic applications that include characteristics related to video and computer games to provide students with engaging and immersive learning experiences that focus on delivering specific educational goals. Furthermore, and as it has been explained in the previous sections, different authors have assumed that games are intrinsically motivating; and consequently, they suggest that the use of this resource in the classroom can be beneficial in the students' learning process (Alessi, \& Trollip, 2001; Cooley, 2015; Garris, Ahlers, \& Driskell, 2002; Prensky, 2001; Oblinger, 2004).

Digital game-based learning was born from social educational needs raised from the existence and usage of new forms of technology, which have significantly changed learners' contemporary thinking patterns and motivation. In this line, Prensky (2001) coined the term digital natives in reference to the people born in XXI century who have grown using digital technology and contrasting them with the rest of population, who have gradually introduced technology to their lives as it was being developed. Thus, it seems that new pedagogical practices and approaches like this one are fundamental to teach and motivate contemporary students, who have been tagged as digital natives.

From a broad pedagogical perspective, Prensky (2001) classified this practice as an approach which mainly focuses on the completion of tasks and role-playing simulations through electronic games. To be considered an approach, digital game-based learning involves a series of learning theories. To this purpose, Margarida, Veloso, Papastergiou and Kordaki (2010) identified three main paradigms connected to digital game-based learning with: behaviorism, cognitivism and constructivism. Firstly, digital game-based learning provides students with stimulus and positive or 
negative reinforcement; thus the learning process happens when there is a change of reaction between them. Secondly, this approach also requires the students' active participation in order to learn, this involves both memorization and problem solving. And thirdly, digital game-based learning involve learning by doing, which implies constructing and interpreting knowledge and applying it in the virtual world according to the learner's own knowledge and experience. In addition to these principles, Kam, Gogolin, Blakemore and Emerick (2013) also stated that students need to be aware of their learning process; this implies reflective learning. Thus, learners should consciously think, analyze, and learn through the reflection of their gaming experience.

In the field of language learning, different researchers have pointed out complimentary theories related to gamebased learning. For example, Dickey (2005) suggested that game-based language learning can reconstruct narrative as an immersive story with elements of participation and consequently promote pragmatic learning through problem-based tasks. Furthermore, game-based language learning promotes students' acquisition of new terminology and language forms by developing mind maps in which they associate symbol, reference, and referent (Casañ-Pitarch, 2017b). This semantic triangle connects a thought to an object or subject (referent), and also a word to an object or subject (Ogden, Richards, Ranulf, \& Cassirer, 1923). As result, the comprehension of referents is based on the individual's previous experience (what they already know), and on the fact that individuals need a reference about the symbol that is represented. Besides, game-based language learning also helps students learn new terminology in a comprehensible and playful way that allow testing functions and practicing what they have learned (Jonassen, Davidson, Collins, Campbell, \& Haag, 1995).

In sum, the connection among serious games, gamification and digital game-based learning needs to be understood in order to implement the digital game-based approach in the foreign language classroom. To this purpose, it is also necessary to combine the ideas introduced in this section with those pedagogical theories involved in the process of learning foreign languages with serious video-games.

\section{Pedagogical Implications in Foreign Language Learning With SERIOUS VideO-Games}

As previously explained, the amount of research and practical cases that are documented within this field have been rising sharply in the decade of the 2010. This can be justified with the technological advances that have been developed during the same period. For example, computers are no longer mandatory to play video-games in the classroom. These devices were space consuming and the educational centers had to afford the expenses derived from the purchase and maintenance of them. Nowadays, most students can use their own smartphones, laptop computers or tablets instead, especially at tertiary education. These gadgets are personal, portable and their connection to the internet is wireless; as result, students can work individually and remotely. Furthermore, there is a wide and rising range of applications and games in the e-stores; they can be purchased and downloaded online, and their prices are generally far lower than they used to be. These facts, among others, have recently changed the perception of education and the world as well. This section focuses on explaining how video-games help students develop their communicative skills in foreign languages; to this purpose, student's learning process has been divided into three stages, as an attempt to organize this section: input, input processing and output (Symons, 1988).

\section{A. Providing Students with Input}

Before students can do any exercise or task, they need to receive a reasonable amount of suitable input; otherwise, they will rely on their previous experience and knowledge, and consequently they will barely advance towards new knowledge. Richards and Renandya (2002) defined input as those sources that are used to start the learning process. It shall be acknowledged that the form of input is important, and to this aim, Krashen (1985) coined the term comprehensible input $(i+l)$, which he defined as the suitable one for successful learning. In this sense, he explained that learners need to confront easy and comfortable tasks but also challenges through new information at a slightly superior level to their own. In other words, input needs to be neither too easy nor too difficult to accomplish learning objectives. Muñoz (2007) extended this definition and claimed that input needs to be authentic, varied, and relevant; and Skehan (1998) added that it should also be experimental in order to activate the learners' long-term memory and help them process the new knowledge. In this sense, video-games are part of a fiction world, but they are also a representation of reality (Galloway, 2004). This type of experimentation and simulation in virtual worlds extends the time of exposure to the contents and consequently it can improve the process of developing and acquiring new knowledge (Roediger, \& Karpicke, 2006). Thus, educational video-games may provide students with a great support in their learning through the completion of challenging problem-solving tasks in specific contexts (Barr, 2013; Griffiths, 2002). At last, from a neuroscientific perspective, Vassiliadis and Rigas (2002) explained that the new information modifies the receivers' behaviors and produces a response (output).

According to these ideas, it seems that there is a well-defined order towards learning that starts with the input that the subjects receive through any of their receptor senses. In language learning, this mainly has to do with hearing and seeing senses. Therefore, if any teaching aims were to provide learners with new information and knowledge, there would be two main possibilities: visual and audio input. On the one hand, visual input can occur through reading or watching. Regarding input through reading, Carver (2000) defined reading as "the process of looking at visually presented words, letters, or other language symbols to gain information or knowledge" (p. 407). Within the education 
field, one of the main supporters of reading is Krashen $(1989,1993,2004)$. He thinks that reading is fundamental in the process of acquiring new knowledge, especially foreign languages. In this sense, through reading, individuals gain new knowledge at their own pace, with the possibility of re-reading, and according to their own cognitive skills. In addition, Franceschini, Gori, Ruffino, Viola, Molteni, and Facoetti (2013) suggested that the use of video-games also enhance learners' attentional abilities, which is relevant feature when dealing with reading since it requires high degrees of concentration and motivation.

Similarly, input through watching is another form of visual input. In this case, watching involves that a subject looks at or observes an action or an object or subject with attention over a period. As result, a subject may compile a series of information that remains in his or her memory, and which can analyze and interiorize for their later imitation or adapted-usage (Karakaş, \& Sariçoban, 2012; Pearson, Fernandez, Lewedeg, \& Oller, 1997). Besides, it seems that visual input through video-games has some benefits due to the connection between action and knowledge. In words of Schenk, Lech and Suchan (2017), video-games promote higher activations in occipital visual areas, such as cuneus, which help increase visual attention and processing. These areas concern the processing of visual stimuli; and these include the inferior temporal gyrus and attention-based areas such as the superior and inferior parietal lobe. As result, the superior parietal lobule receives more visual input and it enhances players' attention to certain actions or objects.

On the other hand, audio input involves the use of listening skills. Listening could be defined as "an active focusing process which allows for a quick and precise analysis of sounds that are heard" (Gilmor, Madaule, \& Thompson, 1989, p. 18). As it happens with visual input, this is another form to transfer information and knowledge from the video-game to the player. However, audio input is not only a way to convey oral messages or to enhance listening skills, it is also related to emotions. In words of Parker and Heerema (2008), the sense of hearing connects to the limbic system, in which memories may be recalled using sounds such as music and voices, whereas loud and sudden sounds might cause a sudden startle reflex in fear, for example. Thus, it seems evident that sounds are connected to emotions and this results in making experiences more real and vivid to the players, and consequently this can be a motivating factor to continue playing as it has been previously explained in table 1 .

In addition to these forms of input, Borba and Zuffo (2016) identified a third possibility, which is known as corporal input and consists in providing players with corporal stimuli that also transfers information. This type of input promotes learners' embodied cognition which concerns the interactions among body, mind, and game environment that can lead to learning (Hacker, 2017). As they explain, the corporal stimulus is a relatively new way to understand virtual experiences since this is a more natural way to explore digital environments. Whereas conventional games only transport players' imagination to a virtual world, some tools can also transport the body inside the synthetic world. In their research, they showed some forms of input through video-games that provide or are controlled by corporal stimuli; in this sense, vibrations or pressure (i.e.: inflating or deflating garments) on the player's body are the main forms of delivering corporal messages that may help the player react in a specific way. Thus, virtual experiences seem to bring more realistic experiences that allow receiving information by means of body stimuli, being this complementary to visuals and sounds.

\section{B. Processing Input}

Once learners have received the necessary input, they should practice in order to process it and consequently interiorize the new information. In this sense, whereas language acquisition is unconscious, learning is a conscious process. In the case of processing communicative skills, learners need to do serious activities consciously in order to activate the unconscious one. This tend to be carried out with drills, which are repetitive exercises that help interiorize new knowledge (Paulston, 1970). De Keyser (1998) defined drills as those activities that encourage "the student to use the language to convey real meaning, while some recently taught rules, the focus of the drill, can be kept in mind" (p. 52). Besides, this learning stage involves that the instructor has to provide feedback to the learners based on their performances (Swain, 1995). In the field of video-games, there are different strategies and exercises to help learners process their communicative skills.

Firstly, players are constantly reading through video-games. In this sense, players need to read texts when they are playing and also when they are not. On the one hand, they need to read all the information shown in the screen. Among others, players need to read game instructions, characters' dialogues, and also their controlled actions, i.e.: 'jump', 'open', 'go', 'collect', 'give' (Griffiths, 2002). On the other hand, they also need to read instructions to learn how to play or what to do in specific moments of the game. This implies that they need to look for information on the net; as result, players have to read official websites, blogs and forums, as well as watching videos (Wang, \& Singhal, 2009; Wilhelmsson, 2011). The comprehension of these texts can be tested when the players is on the game: if they do not follow the instructions, it is likely that they will not fulfill their purpose. In addition, serious games can incorporate comprehension tests, quizzes or some specific tasks to check that players have read and understood the information provided (Erhel, \& Jamet, 2013; Coelho, \& Primo, 2017).

Secondly, when playing video-games players need to continuously listen to messages delivered by the computer or by other players. In this sense, it seems that video-games can be a great help to develop learners listening skills if they practice with suitable video-games for this particular aim, as it can be observed in the results introduced by CalvoFerrer (2017). In this case, this researcher tested the development of listening skills with a video-game in which the player performs the role of an interpreter; in other words, listening to messages and then translating them or some 
fragments. In other video-games, messages can also involve instructions to take actions in order to advance in the game; thus, this fact should be sufficiently motivating to take efforts to listen properly (Cuenca-Minchala, 2017). As it happened in the development of reading skills, video-game designers could also introduce tests and quizzes to check players' comprehension and allowing them to advance provided they fulfill the minimum requirements of the exercise.

Next, some video-games also help develop productive skills, both written and oral. In the case of writing skills, players can train their written language skills responding to blogs, discussing the actions of the video-game with other players in a chat room, or writing their own entries in blogs. According to Liao, Chang and Chan (2018), video-games for enhancing communicative skills can be used to foster imagination, improve learning engagement, and enhance learners' participation. In this sense, there are a series of video-games that can help enhance writing skills, especially those in which real players interact in a virtual world or role-playing games. For example, Squire and Jan (2007) suggested the video-game called The Mad City Mystery, which consist in developing and arguing scientific writing or explanations to decide the cause of a death. This video-game incorporates the need for reflection and critical thinking to solve the criminal cases with written activities. Another example in which writing skills are practiced is Habbo Hotel; this video-game is a hotel where users control an avatar and interact among themselves as if they were in a chat room. As commented, the instructors could suggest their students to practice their new knowledge in some of these videogames; besides, if the students and teachers interact in the same chat room or virtual world, teachers could also monitor learners' progress and provide feedback. This suggestion is possible to be implemented in Second life.

At last, video-games also help enhance speaking skills. Kongmee, Strachan, Montgomery and Pickard (2011) suggested that MMORPG are a good means to practice speaking skills. World of Warcraft, League of Legends, Diablo or Guild Wars are examples of video-games that allow players to talk among themselves to discuss issues of the game. In addition, some serious video-games can be exclusively designed to help improve speaking skills. Advances in speech recognition have given rise to new possibilities and applications. For example, Lingo Online is a video-game which focuses on conversational skills and pronunciation; players practice their speaking skills at the same time they received personalized feedback on their performance. Similarly, Johnson, Vilhjalmsson and Samtani (2005) created the videogames Tactical Levantine Arabic and Tactical Iraqi with the aim of training militaries' conversational skills. In this case, players engage in oral conversations with game characters through automatic speech recognition. This game also incorporates intelligent tutoring to provide feedback based on the learners' individual performances.

\section{Students' Output in the Foreign Language Classroom}

Students will be ready to produce output when they can analyze different forms and choose the most appropriate and accurate ones depending on the specific given context (Swain, 2005). At this output stage, students may notice their errors and mistakes and learn from them (Lyster, 2004). Swain (2005) states that learners need to have enough opportunities to produce language according to the contexts and aims that they have been instructed for. As suggested for comprehensible and meaningful input, teachers should also provide their students with the adequate context for the right output, being this authentic, varied and relevant. In this sense, after drilling to process and interiorize the input recieved, students should be able to implement their new knowledge into a real environment. In the case of languages, their objective would be to reproduce specific language forms in a real scenario in which communication flows in a natural way. To this aim, Nunan (1989) defined tasks as "activities that can stand alone as communicative act in its own right" (p. 10); besides, learners should be able to comprehend, produce and manipulate them while producing authentic language. The main focus of this type of exercise is placed on the meaning rather than the form since the purpose is to promote the development of real communication while practicing the new knowledge (Nobuyoshi, \& Ellis, 1993). Then, in order to list and classify tasks played with video-games, three main possibilities are considered: written, oral, and corporal tasks.

To start with, students can produce both written and oral output by means of different tasks. Two possible tasks can be considered at this point: those happening inside the video-game world and those outside. On the one hand, students continuously need to interact with avatars controlled by other real player. In this sense, they need to practice their language in spontaneous environments in which any language form they know could be useful to communicate with other players. Besides, video-games should also be considered an immersive virtual environment for learning purposes. Thus, language immersion could be defined as the exposure to a target language with the aim of developing it together with various cultural and social skills related to the same language (Cummins, 2009). In this context, the simple act of playing and communicating with other players could be considered a task which involves either speaking or writing. To benefit from the use of video-games in the classroom, teachers could encourage their students to achieve particular goals by means of using certain target language forms. Other researchers have previously introduced some examples with the aim of practicing both oral and written skills. Concerning oral tasks, some other authors have promoted their implementation in the foreign language classroom. For example, researchers such as Canto and Jauregi (2017), Chotipaktanasook and Reinders (2018), Cózar-Gutiérrez and Sáez-López (2016), Jauregi, Canto, Graaff, Koenraad and Moonen (2011), Oliver and Carr (2009), Strachan, Kongmee and Pickard (2016), White (2016) and Zheng, Wagner, Young and Brewer (2009) have previously practiced oral skills with some video-games such as World of Warcraft, Second Life, Everquest, or Minecraft, among others. Most of these tasks had to do with negotiation in a virtual environment. For example, Canto and Jauregi (2017, p. 26) used Second Life to perform a series of oral tasks that involved planning a holiday and reflecting on past holiday experiences, or participating in a cultural television game 
style context between a Dutch and a Spanish team. Similarly, Strachan, Kongmee and Pickard (2016) used World of Warcraft to practice the language forms studied in class through interactive tasks among the students. Concerning written tasks developed with video-games, it is difficult to identify examples occurring inside the virtual world except those based on communicating with other real players in written chats during the gaming time or drills, as explained when describing how to process input. In this sense, it seems there is a lack of video-games that promote writing formal documents on professional or academic issues, for example.

On the other hand, the reality that the players have experienced when gaming can also be used in the classroom with the aim of implementing tasks that allow students to develop their written and oral skills. In this sense, some researchers such as Ferdig and Pytash (2014), Knobel and Lankshear (2016), Peterson (2016) or Sourmelis, Ioannou and Zaphiris (2017), among others, have promoted the development of written skills by writing entries to blogs, participating in forums, interacting in written chats, developing the plot or story of a new video-game, among others. Similarly, concerning the oral register, other researchers such as Chun, Kern and Smith (2016), Goldstein and Driver (2014), Kessler (2013), or Reinders (2012), among others, have promoted or suggested oral tasks that included in-class discussions based on the video-game experience or filming videos on giving advice and tips or providing instructions for the game and uploading them on internet video channels like Youtube.

At last, there is also a relatively new possibility which concerns corporal output. Some video-games are increasingly incorporating body movement to control the game. One of the first video-games that incorporated this technology was Eye Toy, released by Sony Playstation in 2003; since then, there have been several games that are controlled with the body. Within the field of foreign language learning, we have not be able to identify relevant literature that describes features or previous examples. However, other fields of education have used this type of video-games for teaching purposes. Therefore, it could also be possible to use some video-games controlled by body movements to teach content through a foreign language, as it happens in the CLIL approach and it would also result in a language immersion. In this sense, the benefits of using video-games controlled with kinetics would be twofold. On the one hand, it would provide a closer reality of the virtual world, in which the player would experience their learning process by doing. Some authors that have been previously cited (Margarida, Veloso, Papastergiou \& Kordaki, 2010; Sampson \& Karagiannidis, 2002, Cohen, 2007; Jarvis, 2009), suggested that the best possible learning comes from experience and task solving should be the main principle of electronic learning. With kinetics, the learners would have the opportunity to construct and interpret their own knowledge and apply it in the virtual world according to their knowledge and experience. On the other hand, due to its practical nature and close-simulation of reality, these experience would result highly motivating for the students (González, Gómez, Navarro, Cairós, Quirce, Toledo and Marrero-Gordillo, 2016; Lohse, Boyd and Hodges, 2016; Sun, 2015; Yang, Hsieh and Ku, 2015).

\section{DISCUSSION}

This article has aimed at reviewing the relationship between digital game-based learning and the elements related to it along the process of foreign language learning. In the previous sections, a series of definitions, theories, and examples of applications have been introduced; however, this paper would be incomplete without a discussion on the connection of these items. Following these previous explanations and definitions, it seems that the application of the digital gamebased approach in the foreign language classroom could bring some benefits in terms of learners' motivation and extending their time of exposure to learning with a wide range of both conventional and non-conventional exercises and tasks, as well as other resources.

Despite the game-based approach has been used for centuries and the application of video-games for educational purposes has been considered at least since the decade of the 1980s, it seems that this approach has become increasingly popular since the decade of the 2010s. As it has been explained, the last technological revolution (i.e.: Smartphones, Tablets, portable and wireless Internet, more powerful CPU) has led to social and educational changes. In this sense, the new electronic gadgets mentioned in this paper have quickly become part of people's routines; and consequently, it seems that they need to be part of the current education rather than being excluded. Definitely, this approach should be considered a real pedagogical possibility in the field of foreign language learning, and it would also be fundamental that any teacher or instructor learned their benefits and how to implement it in the classroom. In this sense, they should firstly determine the content to be taught in the classroom and then decide which methodology would be the most adequate one to fulfill their particular learning goals.

This paper invites to its readers to critically think how the introduction of electronic and digital gadgets into the game-based approach can offer a wide range of pedagogical possibilities in the field of foreign language teaching as well as in the broad educational field. In particular, video-games have shed light on educational fields for different reasons. For example, video-games provide students with the opportunity to practice or implement their acquired knowledge in virtual simulations that imitates real-life situations and actions happening in the learners' present world. Besides, due to the fact that the nature of these resources is the same or similar to a conventional video-game, they entertain their learners, despite the primordial objective of these is to teach. The emotions and feelings of engagement, competition, satisfaction after fulfilling their achievement, or discovery in the process of learning, among others, are some of the reasons why the implementation of video-games as a pedagogical tool seems to enhance learners' efforts to complete their tasks. 
After defining and connecting three basic concepts within the target context (serious video-games, gamification, and digital game-based learning), the real interest of this paper has been to show how language learners can acquire and develop their language skills. To this aim, both serious and conventional video-games are only 'another' way of learning, which is not necessarily different to other more traditional ones. Therefore, the stages of learning described by Symons (1988) are suitable to explain how learners can develop their language skills in environments gamified with serious video-games as well as conventional ones. Either considering that teachers use serious or conventional videogames, learners should receive some valuable input first which would challenge the current knowledge of the learner. Then, they should have the opportunity to interiorize the contents by means of drilling exercises, before they have the opportunity to do any task. In order to explain this process, this paper has individually shown some particular cases of serious and conventional video-games, as well as results of previous experiments, in which the development of any of the four language skills was tested and analyzed by other researchers.

Regarding the cases that have been introduced in this paper, it seems that video-games can contribute to develop learners' language skills. As it has been shown, video-games can help learners develop their reading, listening, writing and speaking skills as well as providing them with new vocabulary and grammar structures. As it happens in other approaches, the development of these skills needs to be carried out with tasks that promote the use of their knowledge into meaningful contexts. In addition, it has also been commented that the video-game industry has also developed the necessary technology to introduce problem-solving exercises through physical movement. In this case, input and output do not only occur through hearing and seeing but also through body stimuli; learners can consequently carry out their tasks with body movement including hands, legs, waist or face. It seems that this last option enhances playability within virtual-reality scenarios, giving a sense of further liveliness.

At last, based on this discussion, it seems that the future still has lots of possibilities to offer, and gamified proposals and the use of serious video-games in the foreign language classroom require further research and experimental cases to determine and specify their benefits and effects on learners. If any teacher or instructor decides to apply the game-based approach with the support of video-games, either serious or conventional, it would be advisable to carefully design their lesson plan and follow a model of gamification in which the content to be taught should be chosen before the type of game, as it has been suggested with our own previous model (Casañ-Pitarch, 2017a). To end this discussion, this review on the connection among the different elements related to digital game-based learning along the process of foreign language learning has compiled and suggested some possible benefits and present applications of video-games as an educational approach. Newer applications will be determined by new research and the continuous development of artificial intelligence.

\section{CONCLUSION}

As it has been observed, the field of serious games in foreign language learning offers a wide range of pedagogical possibilities to be exploited and developed within the next few years. Their use in the classroom could enhance learners' motivation towards learning foreign languages as well as extending their time of exposure to learning with either conventional or non-conventional resources. The development and use of serious video-games seems that they have become a reality in the present decade since the development of the technology is sufficiently adequate to implement the digital game-based approach in most educational centers. The use of mobile phones, tablets and portable computers allow that students may have both individualized as well as cooperative learning either in the classroom or at home. In the future, this research could move towards an empirical study on the use of serious games in the foreign language classroom, analyzing the benefits of learning foreign languages with video-games and consider how motivation can influence in their learning. To conclude, it shall be acknowledged that future research will also depend on new technological advances, especially those derived from artificial intelligence.

\section{REFERENCES}

[1] Aguiar-Castillo, L., Rufo-Torres, J., De Saa-Pérez, P., \& Pérez-Jimenez, R. (2018). How to Encourage Recycling Behaviour? The Case of WasteApp: A Gamified Mobile Application. Sustainability, 10 (5). Retrieved on 12/06/2018: http://www.mdpi.com/2071-1050/10/5/1544.

[2] Alessi, S., \& Trollip, S. (2001). Multimedia for learning: Methods and development. Boston: Allyn, \& Bacon.

[3] Ausubel, D.P. (1968). Educational Psychology: A Cognitive View. New York: Holt, Rinehart, and Winston.

[4] Barr, M. (2013). Video games in higher education. Proceedings of the 6th annual University of Glasgow learning and teaching conference. Glasgow: The University of Glasgow. Retrieved on 12/03/2018 from http://eprints.gla.ac.uk/78490/1/78490.pdf.

[5] Bellotti, F., Kapralos, B., Lee, K., Moreno-Ger, P., \& Berta, R. (2013). Assessment in and of serious games: an overview. Advances in Human-Computer Interaction, $2013 \quad$ (1). Retrieved on 12/06/2018 from https://dl.acm.org/citation.cfm?id=2484486.

[6] Borba, E., \& Zuffo, M. (2016). Natural to the human interactions with digital interfaces: a new perspective to understand the virtual experiences. Proceedings of the IAMCR Conference (pp. 312-317). Montreal: Universite du Quebec.

[7] Bruner, J.S. (1966). Toward a Theory of Instruction. New York: Norton.

[8] Buchanan, K., \& Elzen, A. (2012). Beyond a Fad: Why Video Games Should Be Part of 21st Century Libraries. Education Libraries, 35(1), 15-33. 
[9] Butler, J. (2016). The role of games in digital learning. Elearning Network. Retrieved on 12/03/2018 from https://www.elearningnetwork.org/the-role-of-games-in-digital-learning/.

[10] Calvo-Ferrer, J. R. (2017). Educational games as stand-alone learning tools and their motivational effect on L2 vocabulary acquisition and perceived learning gains. British Journal of Educational Technology, 48(2), 264-278.

[11] Calvo-Ferrer, J. R. (2018). Juegos, videojuegos y juegos serios: Análisis de los factores que favorecen la diversión del jugador. Miguel Hernández Communication Journal, 9(1), 191-226.

[12] Canto, S., \& Jauregi, M. (2017). Language learning effects through the integration of synchronous socializing network opportunities in language curricula: The case of video communication and Second Life. Language Learning in Higher Education Journal, 7(1), 21-53.

[13] Carver, R.P. (2000). The causes of high and low reading achievement. London: Routledge.

[14] Casañ-Pitarch, R. (2017a). Gamifying content and language integrated learning with serious video-games. Journal of Language and Education, 3(3), 107-114.

[15] Casañ-Pitarch, R. (2017b). Language for specific purposes and graphic-adventure video-games: Supporting content and language learning. Obra Digital, 13(1), 169-183.

[16] Chomsky, N. (1966). Cartesian Linguistics: a chapter in the history of rationalist thought. New York: University Press of America.

[17] Chotipaktanasook, N., \& Reinders, H. (2018). A massively multiplayer online role-playing game and its effects on interaction in the second language: Play, interact, and learn. In B. Zou, \& M. Thomas (eds.), Handbook of Research on Integrating Technology into Contemporary Language Learning and Teaching (pp.367-389). Hershey, PA: IGI Global.

[18] Chun, D., Kern, R., \& Smith, B. (2016). Technology in language use, language teaching, and language learning. The Modern Language Journal, 100(1), 64-80.

[19] Coelho, H., \& Primo, T. (2017). Exploratory apprenticeship in the digital age with AI tools. Progress in Artificial Intelligence, $6(1), 17-25$.

[20] Cohen, M. D. (2007). Reading Dewey: Reflections on the study of routine. Organization Studies, 28(5), 773-786.

[21] Cooley, B. (2015). Detecting learning styles in video games. San Luis Obispo, CA: California Polytechnic State University

[22] Cózar-Gutiérrez and Sáez-López. (2016). Game-based learning and gamification in initial teacher training in the social sciences: an experiment with MinecraftEdu. International Journal of Educational Technology in Higher Education, 13(2). DOI: 10.1186/s41239-016-0003-4.

[23] Cuenca-Minchala, J. P. (2017). Aplicación educativa Lyrics Training en el desarrollo de la competencia auditiva, en estudiantes de los paralelos A y B, del nivel A2 de la Universidad Tecnológica Indoamérica, durante el período 2016 (Master's thesis). Quito: Universidad Central del Ecuador.

[24] Cummins, J. (2009). Bilingual and immersion programs. In M.H. Long, \& C.J. Doughty (eds.), The handbook of language teaching (pp.161-181). Singapore: Blackwell Publishing.

[25] De Freitas, S. I. (2006). Using games and simulations for supporting learning. Learning, media and technology, 31(4), 343-358.

[26] De Keyser, R. M. (1998). Beyond focus on form: cognitive perspectives on learning and practising second language grammar. In C. Doughty and J. Williams (eds.), Focus on form in classroom second language acquisition (pp. 114-138). Cambridge: Cambridge University Press.

[27] Deterding, S., Dixon, D., Khaled, R., \& Nacke, L. (2011). From game design elements to gamefulness: defining gamification. Proceedings of the 15th international academic MindTrek conference: Envisioning future media environments (pp. 9-15). New York, NY: Association for Computing Machinery.

[28] Dickey, M. (2007). Game design and learning: a conjectural analysis of how massively multiple online role-playing games (MMORPGs) foster intrinsic motivation. Educational Technology Research and Development, 55(3), pp.253-273.

[29] Dondlinger, M. J. (2007). Educational video game design: A review of the literature. Journal of applied educational technology, 4 (1), 21-31.

[30] Erhel, S., \& Jamet, E. (2013). Digital game-based learning: Impact of instructions and feedback on motivation and learning effectiveness. Computers, \& Education, 67(1), 156-167.

[31] Escribano, F. (2012). 10 Gamification as the Post-Modern Phalanstère: The video game industry: Formation, present state, and future. In P. Zackariasson and T. L. Wilson (eds.), The video game industry: formation, present state, and future, pp. 198-219. New York and London: Routledge.

[32] Eseryel, D., Law, V., Ifenthaler, D., Ge, X., \& Miller, R. (2014). An investigation of the interrelationships between motivation, engagement, and complex problem solving in game-based learning. Journal of Educational Technology, \& Society, 17(1), 4253.

[33] Ferdig, R.E., \& Pytash, K.E. (2014). Using video games for literacy acquisition and studying literate practices. In Schrier (ed.), Learning, Education and Games (pp. 55-71). Pittsburgh, PA: Carnegie Mellon University.

[34] Franceschini, S., Gori, S., Ruffino, M., Viola, S., Molteni, M., and Facoetti, A. (2013). Action video games make dyslexic children read better. Current Biology, 23(1), 462-466.

[35] Gagnon, D. (1985). Video-games and spatial skills: An exploratory study. Educational Communication and Technology Journal, 33 (4), 263-275.

[36] Galloway, A. R. (2004). Social realism in gaming. Game studies, 4 (1). Retrieved on 06/03/2018 from http://gamestudies.org/0401/galloway.

[37] Garris, R., Ahlers, R., Driskell. J.E. (2002) Games, motivation, and learning: a research and practice model. Simulation, \& Gaming, 33(4). 441-467

[38] Gee, J.P. (2005). Good video games and good learning. Phi Kappa Phi Forum, 85 (2), 33-37.

[39] Gilmor, T., Madaule, P., \& Thompson, B. (1989). About the Tomatis method. Toronto: Listening Centre Press.

[40] Goldstein, B., \& Driver, P. (2014). Language learning with digital video. Cambridge: Cambridge University Press.

[41] González-González, C., \& Blanco-Izquierdo, F. (2012). Designing social video-games for educational uses. Computers, \& Education, 58(1), 250-262. 
[42] González, C. S., Gómez, N., Navarro, V., Cairós, M., Quirce, C., Toledo, P., \& Marrero-Gordillo, N. (2016). Learning healthy lifestyles through active video-games, motor games and the gamification of educational activities. Computers in Human Behavior, 55(1), 529-551.

[43] Gros, B. (2009). Certezas e interrogantes acerca del uso de los videojuegos para el aprendizaje. Comunicación, 7(1), 251-.

[44] Griffiths, M. (2002). The educational benefits of video-games. Education and health, 20(3), 47-51.

[45] Hacker, D. J. (2017). The role of metacognition in learning via serious games. In R. Zheng and M. Gardner, Handbook of Research on Serious Games for Educational Applications, pp. 19-40. Hershey, PA: IGI Global.

[46] Hamari, J., Koivisto, J., \& Sarsa, H. (2014). Does gamification work? A literature review of empirical studies on gamification. Proceedings of 47th Hawaii International Conference on System Sciences (pp. 3025-3034). Hawaii, HO: Institute of Electrical and Electronics Engineers publishing.

[47] Harris, D. W. (2012). An examination of the impact of computer-based animations and visualization sequence on student understanding of Hadley Cells in atmospheric circulation. Baltimore, MD: University of Maryland.

[48] Kaur, N., \& Geetha, G. (2015). Play and learn DS: interactive and gameful learning of data structure. International Journal of Technology Enhanced Learning, 7(1), 44-56.

[49] Jarvis, P. (2009). Learning from everyday life. In P. Jarvis (ed.), The Routledge international handbook of lifelong learning (pp. 19-30). London: Routledge.

[50] Jauregi, K., Canto, S., Graaff, R.D., Koenraad, T., \& Moonen, M. (2011). Verbal interaction in Second Life: Towards a pedagogic framework for task design. Computer Assisted Language Learning, 24(1), 77-101.

[51] Jonassen, D., Davidson, M., Collins, M., Campbell, J., \& Haag, B. (1995). Constructivism and computer-mediated communication in distance education. American journal of distance education, 9(2), 7-26.

[52] Johnson, W.L., Vilhjalmsson, H., and Samtani, P. (2005). The tactical language training system. Proceedings of the First Conference on Artificial Intelligence and Interactive Digital Entertainment (pp.11-40). Marina del Rey, CA: Center for Advanced Research in Technology for Education

[53] Kam, H. J., Gogolin, G., Blakemore, D., \& Emerick, G. (2013). Playing online games on Facebook: The conscious and unconscious learning in database design. Proceedings of the Frontiers in Education Conference (pp. 514-516). Oklahoma City, OK: Oklahoma State University.

[54] Karakaş, A., \& Sariçoban, A. (2012). The impact of watching subtitled animated cartoons on incidental vocabulary learning of ELT students. Teaching English with Technology, 12(4), 3-15.

[55] Kessler, G. (2013). Collaborative language learning in co-constructed participatory culture. Calico Journal, 30(3), $307-322$.

[56] Kirriemuir, J., \& McFarlane, A. (2004). Report 8: Literature review in games and learning. Futurelab Series. Retrieved on 06/03/2018 from http://www.coulthard.com/library/Files/kirriemuir-futurelabs_2004_gamesreview.pdf.

[57] Knobel, M., \& Lankshear, C. (2016). Digital media and literacy development. In A. Georgakopoulou, \& T. Spilioti (Eds), The Routledge handbook of language and digital communication, 151-165. London: Routledge.

[58] Kongmee, I., Strachan, R., Montgomery, C., \& Pickard, A. (2011). Using massively multiplayer online role playing games (MMORPGs) to support second language learning: Action research in the real and virtual world. Proceedings of the 2nd Annual IVERG Conference: Immersive Technologies for Learning - Virtual Implementation. Middlesborough: Northumbria Research Link. Retrieved on 12/03/2018 from http://nrl.northumbria.ac.uk/279/1/kongmee\%20iverg\%20paper2.pdf.

[59] Krashen, S. (1985). The input hypothesis: Issues and implications. Redding, CA: Longman.

[60] Krashen, S. (1989). We acquire vocabulary and spelling by reading: Additional evidence for the input hypothesis. The modern language journal, 73(4), 440-464.

[61] Krashen, S. D. (1993). The Case for Free Voluntary Reading. Canadian Modern Language Review, 50(1), 72-82.

[62] Krashen, S. D. (2004). The power of reading: Insights from the research: Insights from the research. Santa Barbara, CA: ABCCLIO.

[63] Lakoff, G. (1971). On generative semantics. In D. Steinberg \& L. Jakobovits (Eds.), Semantics: An Interdisciplinary Reader in Philosophy, Linguistics and Psychology (pp. 232-296). Cambridge: Cambridge University Press.

[64] Liao, C.C., Chang, W.C., \& Chan, T. W. (2018). The effects of participation, performance, and interest in a game-based writing environment. Journal of Computer Assisted Learning, 27(1). DOI: 10.1111/jcal.12233.

[65] Lohse, K.R., Boyd, L.A., \& Hodges, N.J. (2016). Engaging environments enhance motor skill learning in a computer gaming task. Journal of motor behavior, 48(2), 172-182.

[66] Loveless, A., \& Williamson, B. (2013). Learning identities in a digital age: Rethinking creativity, education and technology. London: Routledge.

[67] Lyster, R. (2004). Research on form-focused instruction in immersion classrooms: Implications for theory and practice. Journal of French language studies, 14(3), 321-341.

[68] Malone, T.W. (1981). What makes things fun to learn? A study of intrinsically motivating computer games. Pipeline, 6(2), 5051.

[69] Malone, T.W., \& Lepper, M.R. (1987). Making Learning Fun: A Taxonomy of Intrinsic Motivations for Learning. In R.E. Snow \& M.J. Farr (Eds.), Aptitude, Learning, and Instruction (Volume 3): Cognitive and Affective Process Analyses. Hillsdale, N.J.: Erlbaum.

[70] Margarida, R., Veloso, A., Papastergiou, M., \& Kordaki, M. (2010). Design of a Computer Game for an Information Technology Class. Proceedings of Videojogos (pp. 51-60). Lisboa: Universidade Técnica de Lisboa.

[71] Molin, G. (2017). The role of the teacher in game-based learning: A review and outlook. In M. Ma and A. Oikonomou (eds.), Serious Games and Edutainment Applications, pp. 649-674. New York: Springer.

[72] Muñoz, C. (2007). CLIL: Some thoughts on its psycholinguistic principles. Revista española de lingüística aplicada, 7(1), 1726.

[73] Nobuyoshi, J., \& Ellis, R. (1993). Focused communication tasks and second language acquisition. ELT journal, 47(3), $203-210$.

[74] Nunan, D. (1989). Designing tasks for the communicative classroom. Cambridge, UK: Cambridge University Press. 
[75] Oblinger, D. (2004). The next generation of educational engagement. Journal of interactive media in education, 8(1). DOI: 10.5334/2004-8-oblinger.

[76] Ogden, C.K., Richards, I.A., Ranulf, S., \& Cassirer, E. (1923). The meaning of meaning: a study of the influence of language upon thought and of the science of symbolism. London: Routledge.

[77] Oliveira, L.R., Correia, A.C., Merrelho, A., Marques, A., Pereira, D.J., \& Cardoso, V. (2009). Digital games: possibilities and limitations - The spore game case. In T. Bastiaens, J. Dron, \& C. Xin (Eds.), Proceedings of E-Learn: world conference on elearning in corporate, government, healthcare, and higher education (pp. 3011-3020). Chesapeake, VA: Association for the Advancement of Computing in Education.

[78] Oliver, M., \& Carr, D. (2009). Learning in virtual worlds: Using communities of practice to explain how people learn from play. British Journal of Educational Technology, 40(3), 444-457.

[79] Parker, J. R., \& Heerema, J. (2008). Audio interaction in computer mediated games. International Journal of Computer Games Technology, 2008(1). doi:10.1155/2008/178923

[80] Paulston, C.B. (1970). Structural pattern drills: A classification. Foreign Language Annals, 4(2), 187-193.

[81] Pearson, B.Z., Fernandez, S. C., Lewedeg, V., \& Oller, D. K. (1997). The relation of input factors to lexical learning by bilingual infants. Applied Psycholinguistics, 18(1), 41-58.

[82] Pechenkina, E., Laurence, D., Oates, G., Eldridge, D., \& Hunter, D. (2017). Using a gamified mobile app to increase student engagement, retention and academic achievement. International Journal of Educational Technology in Higher Education, 14(1). DOI: 10.1186/s41239-017-0069-7.

[83] Peterson, M. (2016). Computer games and language learning. Berlin: Springer.

[84] Piaget, J. (1952). The Language and Thought of the Child. London: Routledge and Kegan-Paul.

[85] Prensky, M. (2001). Digital natives, digital immigrants part 1. On the horizon, 9(5), 1-6.

[86] Qian, M., \& Clark, K. R. (2016). Game-based Learning and 21st century skills: A review of recent research. Computers in Human Behavior, 63 (1), pp. 50-58.

[87] Robson, K., Plangger, K., Kietzmann, J. H., McCarthy, I., \& Pitt, L. (2015). Is it all a game? Understanding the principles of gamification. Business Horizons, 58 (4), 411-420.

[88] Roediger, H. L., \& Karpicke, J. D. (2006). Test-enhanced learning taking memory tests improves long-term retention. Psychological science, 17(3), 249-255.

[89] Reinders, H. (2012). Digital games in language learning and teaching. Basingstoke: Palgrave Macmillan.

[90] Richards, J. C., \& Renandya, W.A. (Eds.). (2002). Methodology in language teaching: An anthology of current practice. Cambridge: Cambridge University Press.

[91] Sampson, D., \& Karagiannidis, C. (2002). Personalised learning: educational, technological and standarisation perspective. Digital Education Review, 4(1), 24-39.

[92] Schenk, S., Lech, R.K., \& Suchan, B. (2017). Games people play: How video games improve probabilistic learning. Behavioural brain research, 335, 208-214.

[93] Selwyn, N., \& Bulfin, S. (2016). Exploring school regulation of students' technology use-rules that are made to be broken? Educational Review, 68(3), 274-290.

[94] Silvern, S. B. (1986). Classroom Use of Video-games. Educational Research Quarterly, 10(1), 10-16.

[95] Skehan, P. (1998). A cognitive approach to language learning. Oxford: Oxford University.

[96] Sourmelis, T., Ioannou, A., \& Zaphiris, P. (2017). Massively Multiplayer Online Role Playing Games (MMORPGs) and the 21st century skills: A comprehensive research review from 2010 to 2016. Computers in Human Behavior, 67(1), 41-48.

[97] Squire, K. D., \& Jan, M. (2007). Mad City Mystery: Developing scientific argumentation skills with a place-based augmented reality game on handheld computers. Journal of science education and technology, 16(1), 5-29.

[98] Strachan, R., Kongmee, I., \& Pickard, A. (2016). Using massively multiplayer role playing games (MMORPGs) to support second language learning: A case study of the student journey. In K. Terry, \& A. Cheney (eds.), Utilizing Virtual and Personal Learning Environments for Optimal Learning. Advances in Educational Technologies and Instructional Design (pp. 87-110). Hershey, PA: IGI Global.

[99] Sun, H. (2015). Operationalizing physical literacy: the potential of active video games. Journal of Sport and Health Science, 4(2), 145-149.

[100] Susi, T., Johannesson, M., y Backlund, P. (2007). Serious games: An overview. Uppsala: DiVA. Retrieved on 12 March 2018 from http://www.diva-portal.org/smash/get/diva2:2416/FULLTEXT01.pdf.

[101] Swain, M. (1995). Three functions of output in second language learning. In G. Cook and B. Seidlhofer (eds.), Principles and practice in applied linguistics: studies in honour of H. G. Widdowson (pp. 158-64). Oxford: Oxford University Press.

[102] Symons, C. R. (1988). Function point analysis: difficulties and improvements. IEEE transactions on software engineering, $14(1), 2-11$.

[103] Vassiliadis, V. G., \& Rigas, A. G. (2002). Phase recovery of a stochastic point process system. In P. Liatsis (ed.), Recent trends in multimedia information processing (pp. 37-43). Manchester: World Scientific.

[104] Wang, H., \& Singhal, A. (2009). In U. Ritterfeld, M. Cody, \& P. Vorderer (eds.), Entertainment-education through digital games. Serious games: Mechanisms and effects (pp. 271-292). London: Routledge.

[105] Werbach, K. (2014). ReDefining Gamification: A Process Approach. In A. Spagnolli, L. Chittaro, and L. Gamberini (eds.), Persuasive Technology, pp. 266-272. New York: Springer.

[106] Werbach, K. and Hunter, D. (2012). For the win: How game thinking can revolutionize your business. Philadelphia, PA: Wharton Digital Press.

[107] White, K.D. (2016). Cultures and communities in the virtual world: Beginning the exploration. Journal of Language Learning Technologies, 43(2), 28-56.

[108] Wilhelmsson, A. (2011). Presenting learning possibilities through branching storylines: A case study of epic proportions (Master Thesis). Skövde: University of Skövde. 
[109] Wilson, J.P. (2014). International human resource development: Learning, education and training for individuals and organisations. Bingley: Emerald Group Publishing.

[110] Yang, Y. F., Hsieh, M. C., \& Ku, M. T. (2015). Development of a kinesthetic learning system for schoolchildren's baseball learning based on competence motivation theory: its effect on students' skill and motivation. Acta Oeconomica, 65(2), 295-307.

[111] Zheng, D., Wagner, M.M., Young, M.F., \& Brewer, R.A. (2009). Negotiation for action: English language learning in gamebased virtual worlds. Modern Language Journal, 9(1) 3, 489-511.

[112] Ziegler, N. (2016). Taking technology to task: Technology-mediated TBLT, performance, and production. Annual Review of Applied Linguistics, 36(1), 136-163.

Ricardo Casañ-Pitarch (Benicassim, 18 October 1983) is a $\mathrm{PhD}$ holder in Applied Linguistics from Universitat Jaume I (Castellón, Spain) since 2014. His major field of study is genre and language analysis and his $\mathrm{PhD}$ dissertation focused on the analysis of the language used in banks' corporate websites. Since 2016, he is also interested in the study of language acquisition processes with the support of video-games and other digital resources.

Dr. Casañ-Pitarch is currently working as a PhD Assistant Professor at Universitat Politècnica de València (city of València, Spain), where he teaches English Language to industrial engineering students. In addition to his teaching position, some of his most relevant publications within the field of video-games and language acquisition are Language for Specific Purposes and GraphicAdventure Videogames: Supporting Content and Language Learning (Vic, Spain: Obra digital, 2017) and Storyline-Based Videogames in the FL Classroom (Barcelona, Spain: Digital Education Review, 2017). 